\title{
The Geographies of Protest and Public Space in Mid-nineteenth-century London: The Hyde Park Railings Affair
}

\section{Hannah Awcock}

School of Geography, Geology and Environment, University of Hull

\begin{abstract}
On 23 July 1866, a protest took place in Hyde Park, London, which provides a lens through which to analyse historical struggles over access to, and control of, public space. What began as a protest in favour of manhood suffrage became a conflict over the character and purpose of the park. It sparked public debates about which groups of people could access Hyde Park, and what activities were acceptable within it. These debates raise questions about who was entitled to make such decisions and the impact of these decisions on London's radical culture. This article uses newspaper articles and parliamentary debates to explore the dispute which unfolded both before and after the Hyde Park Railings Affair. In doing so, it furthers our understanding of the geographies of protest and the ongoing negotiation of public space.
\end{abstract}

\section{Introduction}

The availability of freely accessible public space in which to hold protests, meetings, and rallies is an important resource for social movements and activists. In recent years, the increasing privatisation and regulation of public spaces has raised concerns over the character and health of public space in cities. ${ }^{1}$ However, debates about access to, and control of, public space are nothing new. Drawing on literature about public space and the historical geographies of protest, this article looks at such conflicts through the lens of the Hyde Park Railings Affair, a protest organised by the Reform Leaguea group established in 1865 to campaign for all-male suffrage - that took place in Hyde Park in London on 23 July 1866.

Hyde Park is made up of 350 acres of land in Westminster in central London. It is one of London's Royal Parks, owned by the Crown but placed 'in the care of the nation' by the monarch and managed by the Government. ${ }^{2}$ This situation has caused confusion in the past about who had the right to control and police the park. ${ }^{3}$ Hyde Park was first opened to the public by Charles I in 1637 and it has since become known as the 'People's Park. ${ }^{\prime 4}$ As the nineteenth century progressed, rapid industrialisation and urbanisation led to increasing panic amongst the upper classes about the physical and social condition of the working-class urban population. Public parks were one of the most popular solutions, and by the end of the century most large urban areas had at least one. 'Rational' recreation, as well 
as the opportunity to mix with other classes, was seen as a method of social and moral improvement. ${ }^{6}$ Hyde Park predated this phenomenon, but it would still have been understood in these terms during the nineteenth century.

The awareness of the social, moral, and physical importance of accessible open spaces contributed to conflict over access to parks, commons, and other open spaces around Britain. Groups such as the Commons Preservation Society and Commons Protection League were founded to fight against enclosures and protect public access to open land. ${ }^{7}$ Examples which have been subjected to historical analysis include Mousehold Heath on the outskirts of Norwich (1857-1884), Berkhamsted Common in Hertfordshire (1866-70), Plumsted in Kent (1876), and Knole Park in Sevenoaks, Kent (1883-5). ${ }^{8}$ Most relevant to this article is Anthony Taylor's analysis of radicals' struggles to access space for meeting and organising in London between 1848 and $1880 .{ }^{9}$ This article builds on this work by conducting an explicitly geographical analysis of the Hyde Park Railings Affair, exploring the contested understandings of both public space in London, and Hyde Park as a place.

Over the centuries, Hyde Park has developed a symbolic association with free speech and dissent. Until 1783, public executions in London took place at Tyburn, at the corner of Hyde Park where Marble Arch now stands. ${ }^{10}$ The condemned were entitled to make a speech to the crowd before their execution; some of them used the opportunity to express a political opinion. Intended as a sombre warning and deterrent against future crimes, the hangings were instead carnivalesque, a spectacle that entertained and fascinated the watching crowds. John Michael Roberts argues that 'scaffold culture' left its mark on Hyde Park, creating a lasting association between the park and moral, emotional, and public speech; the "traces of the 'last dying speeches' had inscribed a form of platform politics in the urban fabric of Hyde Park." ${ }^{11}$ Roberts argues that political groups that used Hyde Park during the nineteenth century, including the Reform League, implicitly built upon these 'traces.' The first large-scale demonstrations in the park took place in 1855, against the unpopular Sunday Trading Laws. As such, the Reform League were both drawing from and contributing to a developing radical tradition in the park.

In critically analysing the historical geographies of the Hyde Park Railings Affair, this article utilises two main sources. The first is Hansard, a largely verbatim report of the debates in both Houses of the British Parliament, going back to the late eighteenth century. It allows us to analyse the opinions, arguments, and rhetoric of Britain's politicians. The second source is newspapers. These printed a variety of types of text, including: Parliamentary debates, newspaper editorials, reports and 
'eyewitness accounts' of the demonstration itself, reports of other meetings where the demonstration was discussed, open letters, and letters to the editor. Although the Hyde Park Railings Affair took place in London, provincial newspapers followed events in the capital, and both electoral reform and access to public space was a national issue, so the riots were discussed in many British newspapers. Like all historical sources, however, newspapers cannot be taken at face value: they are "gatekeepers and filterers of ideas." ${ }^{12}$ Editors and journalists make decisions about which stories are covered, and they shape how those stories are interpreted and received. ${ }^{13}$ In this way, newspapers contribute to the (re)production of dominant political discourses. In relation to protest, this often entails "delegitimization and marginalization of protest groups that challenge established orders." ${ }^{14}$ As such, newspapers need to be used carefully and critically by researchers, particularly in the context of protests. In this case, the political leanings of all the newspapers analysed were considered in order to understand how they might influence the coverage of the demonstration.

The sources contain a wide range of arguments about holding demonstrations in Hyde Park, from a variety of actors, including: the Government, the Metropolitan Police, opposition politicians, the demonstration's organisers, political reformers, newspaper editors and journalists, political commentators, and members of the public. Admittedly, those whose views are considered here are not representative of society as a whole; they are the predominantly male elites who had enough social and political capital to publicise their opinions. It is widely acknowledged that the voices and perspectives of those who participated in historical protests and riots are largely absent from the archives, and the Hyde Park Railings Affair is no exception. ${ }^{15}$ In response to this issue, Carl Griffin advocates concentrating on how actions are perceived rather than how they were intended. ${ }^{16}$ We cannot know why participants in the Hyde Park Railings Affair took part, and although the Reform League's public reasons for organising the demonstration have been preserved, we do not know if they were also the reasons that the committee gave in private. What we do have access to is how certain people responded to the events of the Hyde Park Railings Affair. As such, those responses are what are analysed in this article.

The rest of this article is made up of five substantive sections. In the next section, I contextualise this research by considering the literature on public space and the historical geographies of protest. The second section describes what took place both before and during the Hyde Park Railings Affair. The third section outlines the wide-ranging arguments made about the suitability and acceptability of holding a demonstration in Hyde Park. The fourth section explores the role of social norms in these debates, considering how normative definitions of acceptable behaviour in the park were both utilised 
and negotiated by supporters and opponents of the Hyde Park Railings Affair. The fifth section examines the intersections of class, power, and geography in the Affair, by analysing arguments about who had the power to influence Hyde Park as a space, and which groups had a right to access it. The final section offers some concluding comments.

\section{The Historical Geography of Public Space and Protest}

For many scholars, public space is an essential component of a functioning democracy. ${ }^{17}$ What public space actually is, however, is harder to pin down. Public space can be defined as "[s]pace to which all citizens have a right of access." 18 This definition excludes non-citizens however, such as visitors and non-naturalised migrants, and does not acknowledge that this right is rarely absolute; it is often contingent on factors such as behaviour and appearance. The right to access public space is not protected in law, and there is little legal difference between land that is publicly and privately owned. There is a discursive difference, however; publicly owned space is understood to be distinctive.${ }^{19}$ Setha M. Low has argued that public space is socially constructed, produced through a combination of everyday use by different groups and debates, both cooperative and competitive, about what the space represents. ${ }^{20}$ Don Mitchell has also written extensively on the construction and contestation of public space. ${ }^{21} \mathrm{He}$ argues that public space is produced through the struggle between two conflicting understandings of its primary purpose: protest and debate, and relaxation and leisure. ${ }^{22}$ Mitchell's work focusses on America in the twentieth century, but as this article will demonstrate, conflict between these two contradictory understandings of public space was also present in mid-nineteenthcentury London.

Another aspect of Mitchell's work which connects to the Hyde Parks Railings Affair is his discussion of the control of space as a proxy for regulating free speech and dissent. Mitchell uses US Supreme Court rulings to argue that over the course of the twentieth century protests were increasingly controlled and limited through the regulation of space. Rather than limit dissent itself, authorities placed increasingly strict controls on where protest was tolerated, effectively limiting dissent whilst still being able to claim it was supported. ${ }^{23}$ Similar spatialized tactics of control were present in nineteenthcentury Britain. Katrina Navickas explores the struggles of working-class radical movements in the north of England to claim space in which to meet. ${ }^{24}$ The authorities recognised that such movements would suffer if they could not access space in which to meet and organise, so employed numerous tactics to restrict working class access to space. Like the US Supreme Court, British authorities tried to control dissident voices by ensuring they did not have access to spaces in which they could be heard. 
Anthony Taylor has argued that this conflict was particularly tense in London for several reasons. One is that the expanding size of the city made open land on the outskirts of London increasingly difficult to access. Another factor was the presence of central Government in Whitehall; the Metropolitan Police answers directly to the Home Office, and any challenge to authority in London was perceived as a challenge to the Government. ${ }^{25}$ Historian Lisa Keller's work on the balance between order and free speech in London and New York in the nineteenth century explores how this conflict between the authorities and dissenting groups played out in the city's public spaces. ${ }^{26}$ The significance of access to space for campaign groups helps to explain why groups such as the Reform League, who's primary concern was electoral reform, would divert their efforts in order to campaign for the right to hold mass meetings in Hyde Park.

It is also important to recognise that Mitchell, Navickas, and Taylor's work, as well as the historical geographies of protest more generally, engages with a broader argument made by Doreen Massey. ${ }^{27}$ Massey contends that space is inherently political, and that space is politicised by its potential for change. For Massey, space is "always under construction," produced by juxtapositions, connections, interactions, and relations. ${ }^{28} \mathrm{It}$ is worth emphasising that this process is not always amicable; space is often produced through antagonism, conflict, and struggle. ${ }^{29}$ The literature discussed here provide examples of space's contested potential, with conflicting interests vying for control over what space will become. As I shall illustrate, Hyde Park's potential to be changed, both physically and in terms of the rules and social norms that governed it, fuelled the debate about the Hyde Park Railings Affair.

This paper will also build on Christina Parolin's exploration of radical cultures in London between 1790 and c.1845. Parolin argues that the sites in which such radical politics occurred shaped the politics that occurred within them. ${ }^{30}$ This paper will extend this argument, drawing on scholarship about contemporary protest to argue that radical politics also shaped, and continues to shape, the spaces in which they occur. ${ }^{31}$ The argument that space, place, and protest are mutually constitutive is widely accepted by geographers. ${ }^{32}$ For example, Sam Halvorsen's work on the 2011 Occupy movement in London explores how the protesters constructed space, but were also constrained by the spatial characteristics of the sites of their occupations..$^{33}$ Mattias Wahlström argues that space is constructed through conflict between protesters and protest policing, highlighting the importance of analysing the perspectives of authorities and elites as well as protesters. ${ }^{34}$ This article explores how the mutual constitution of space through protest connects to debate around the maintenance and contestation of public space. 


\section{The Hyde Park Railings Affair: A Struggle for Public Space}

Parliamentary reform in Britain had been an important political issue since the late eighteenth century. The 1832 Reform Act had reduced the number of rotten boroughs and enfranchised around 8 per cent of the male population, but for many this was not enough. ${ }^{35}$ The Chartists had suffered a fatal loss of momentum in 1848 , but there were a number of other, more moderate, groups that grew up in their place. ${ }^{36}$ In 1865 , the Reform League was established to campaign for universal male suffrage; the barrister Edmond Beales was elected President. ${ }^{37}$ In 1866, the recently-elected Liberal Government proposed a bill that would reduce the property qualification for voters from $f 10$ to $f 7$. Although falling far short of the Reform League's hopes, they gave it their support. ${ }^{38}$ Nevertheless, the bill failed in early 1866, bringing the Government down with it. In response, the Reform League organised a demonstration in London, consisting of a march through the city before a rally in Hyde Park. Arranged for 23 July, it would become known as the Hyde Park Railings Affair.

On 17 July, Richard Mayne, the Commissioner of the Metropolitan Police, published a proclamation banning the Reform League's rally. He argued that the meeting was "inconsistent with the purposes for which the park is thrown open to and used by the public" and that "such an assemblage there of large numbers of persons is calculated to lead to riotous and disorderly conduct, and to endanger the public peace." ${ }^{39}$ The Reform League immediately questioned the legality of this ban. Edmond Beales wrote an open letter in reply, arguing that Mayne had no right to ban the demonstration. ${ }^{40}$ The Executive Committee of the League decided to challenge the ban by attempting to continue with the demonstration as planned; marching to Hyde Park, demanding entry, and leaving peacefully if they were denied. ${ }^{41}$ Ironically, the ban only increased the numbers and the determination of the marchers, heightening tensions and increasing the chance of violence. ${ }^{42}$

On the day of the demonstration, the gates of Hyde Park were closed at 5 o'clock in the evening. ${ }^{43}$ Upon arriving at Marble Arch, Edmond Beales and other leading members of the Reform League advanced towards the lines of police guarding the gates, requesting that they be allowed into the park. When this request was refused, they retreated. ${ }^{44}$ The Executive Committee of the League and some of the marchers continued to Trafalgar Square where they held a peaceful rally. ${ }^{45}$ Despite the Reform League distributing leaflets urging protesters to proceed to Trafalgar Square if they were denied entry and not to break into the park, a large number of people remained behind and discovered that with relatively little effort the cast iron railings surrounding the park could be pulled down. ${ }^{46}$ In this way protesters broke through the boundaries of the park at several different locations, including Marble Arch, Knightsbridge, Park Lane, and Bayswater Road. ${ }^{47}$ The police were unable to prevent protesters 
from entering the park from multiple directions. In the resulting clashes, protesters used stones, fenceposts, and other materials found within the park as weapons against the police. There were injuries on both sides, but no fatalities, and between forty and seventy protesters were arrested..$^{48}$ It was several days before the disturbances in the Park subsided.

As Richard Mayne and Edmond Beale's initial exchange demonstrates, the debate about the ban and its validity was, from the very beginning, based on conflicting understandings of what kinds of behaviour were appropriate in Hyde Park, and who had the right to make such decisions. It is to this theme that I shall now turn.

\section{The Debate: Contested Understandings of Hyde Park}

The Government and the Metropolitan Police clearly stated their argument against the Reform League holding a demonstration in Hyde Park. It had two elements to it. The first was that "such assemblages of men meeting in Hyde Park might lead, and probably would lead, to riotous or disorderly conduct." ${ }^{49}$ The second was that the demonstration "certainly would interfere with the recreation of quiet and orderly people, for whom the parks, the property of the Crown, are open, and not for the purposes of such meetings." ${ }^{50}$ This statement was made by the Home Secretary, Spencer Walpole, in the House of Commons on 19 July. To Walpole, the demonstration and the risk of violence that accompanied it was not in keeping with Hyde Park's purpose, which was "the recreation of quiet and orderly people." ${ }^{51}$ Walpole later stated that he hoped the ban would "not be interpreted as being intended in the least degree to prevent the holding of ordinary public meetings for political discussion, but simply for the preservation of the public peace." ${ }^{52}$ Walpole was foreshadowing the arguments that the US Supreme Court would make a century later, by arguing that it was not the demonstration itself he opposed, but its location. Liberal authorities can use spatially-selective restrictions to "silence dissident speech in the name of its promotion and regulation." ${ }^{13}$ In this way, they are able to simultaneously maintain order, silence dissent, and retain their liberal credentials.

There were many who agreed with the Home Secretary and the Government that the demonstration did not fit with what they perceived as the purpose of the park, recreation. For example, an editorial in the Liverpool Mercury on 26 July stated that "A right to hold public meetings in the parks for one purpose would imply a right to hold public meetings for all purposes; and to admit such a right would be to spoil the parks as places of quiet recreation for quiet people. ${ }^{154}$ Statements such as this highlight Mitchell's argument about the conflicting purposes of public space: protest and peaceful recreation. ${ }^{55}$ To many social and political elites at the time, the two purposes were mutually exclusive. The Morning 
Post, a daily London newspaper whose coverage of the Hyde Park Railings Affair was critical of the Reform League and their supporters, agreed that the demonstration was likely to cause violence: "both in regards to its members and the characters of the individuals composing it, the Reform meeting of Monday next would be much more likely to lead to disorder and a breach of the peace than to promote the objects with which that assemblage is to be convened." ${ }^{56}$

Those who supported the Reform League in holding the demonstration in Hyde Park objected to these arguments on several fronts. One defence was that the disturbance of other park users caused by the demonstration would be minimal. An editorial in the Daily News, for example, argued that the park is big enough to accommodate multiple uses: "twenty political meetings might be held all at once with all the pomp and circumstance of banners and processions, and not one of her MAJESTY's peaceful subjects be the wiser or the worse for it." ${ }^{157}$ This commentator is suggesting that Hyde Park can accommodate both of the conflicting purposes of public space which implies that, for some at least, protest and recreation were not mutually exclusive activities.

A more fundamental argument for the Reform League holding their demonstration in the park was that Hyde Park was not only a suitable location for political demonstrations, but that it was actually much more suitable than other locations. Holding a meeting in Hyde Park would cause much less disruption than in a busy street or square, for example. As the Leeds Mercury argued, "Hyde Park is a large open space ... A public meeting in this out-door open space would injure nobody, obstruct no traffic, damage no property, do no harm in any way." ${ }^{58}$ To defenders of the right to protest in Hyde Park, these characteristics made it an ideal location for mass political meetings. Scholars of contemporary geographies of protest argue that the physical landscape is an important factor in shaping how protest unfolds. ${ }^{59}$ In the case of Occupy London, the main camp's position next to a busy thoroughfare allowed activists to have productive encounters with passers-by, giving them the opportunity to raise awareness of the issues they were protesting. ${ }^{60}$ The Reform League and other nineteenth-century radicals were similarly keen to exploit the advantages offered by the physical environment of Hyde Park.

Opponents of the Reform League's plan to hold a demonstration in Hyde Park argued that there were plenty of other locations where such a meeting could be held. For example, in an editorial published in The Caledonian Mercury (Edinburgh), the author argued that the right to protest was not under threat: 
Reform meetings have been held without hindrance on Primrose Hill. The police would not dream of interfering with an open-air meeting on Wormwood Scrubs, Hampstead Heath, or Clapham Common, where there is ample space for as many thousands are as likely to assemble in support of Reform. Again, there are scores of halls in London in which public meetings might be held without the smallest fear of hindrance from the police. ${ }^{61}$

This is not how radicals and reformers saw the situation, however. In an open letter to the Reform League, well-known radical John Bright encouraged Londoners to assert their right to meet in public, which was being limited from all sides: "To meet in the streets is inconvenient, and to meet in the parks is unlawful-this is the theory of the metropolis!"62 Mason Jones, Chairman of the Reform League, elaborated on this lack of opportunity for mass meetings in an open letter to Spencer Walpole:

You say you would not interfere with the meeting if it was held elsewhere; but I ask where are the masses of your unenfranchised countrymen to meet? Nearly all the open spaces in the metropolis have been enclosed ... What is the use of admitting a right in the abstract, if you practically prevent the application of that right?

In the first half of the nineteenth century, the Government and social elites tried to supress movements for reform and workers' rights. As previously discussed in relation to Katrina Navickas's and Anthony Taylor's work, one of the methods used to achieve this was limiting the opportunities for radicals and reformers to meet and speak in public. ${ }^{63}$ Campaign groups such as the Reform League struggled to find spaces in which they could meet, an essential element in the reproduction of such movements as it enabled groups to reach consensus, plan, boost morale, and recruit. ${ }^{64}$ For radicals such as John Bright and Mason Jones, the debate over the Reform League's right to hold meetings in Hyde Park was part of a much wider struggle for popular movements to claim space.

The issue of ownership was also contentious. Antonia Layard argues that we should work within the discourses and structures of property to construct public spaces. ${ }^{65}$ Multiple groups used a language of ownership and legality in order to establish and justify their right to control Hyde Park as a public space. The Government argued that Hyde Park belonged to the Crown and as a result, the people had no inherent right to use it. In a speech in the House of Commons on 24 July 1866, Spencer Walpole referred to a legal report that the Government had commissioned in the wake of the 1855 Sunday Trading Riots. Walpole quoted extensively from the report, including the following; "the authority to close and exclude the public from the Parks is that which every landowner has to prevent the public from trespassing on his lands." ${ }^{\prime \prime 6}$ The Reform League's supporters argued that the public did have an 
inherent right to access and use the park. ${ }^{67}$ Some argued that the Park did in fact belong to 'the people' rather than the Crown. ${ }^{68}$ This argument was based on the fact that it was taxes, paid by the people, which funded the park's upkeep. For example, an editorial in Reynold's Newspaper, a radical-leaning weekly newspaper published in London, declared that Sir Richard Mayne was attempting to "prevent the people of London from assembling, for a lawful purpose, in one of their own places of public resort-in a place belonging to the public, and paid for out of the public's money." ${ }^{\prime 69}$

The debate over whether the Reform League had the right to hold a mass meeting in Hyde Park, and whether the Government had a right to prevent such a meeting, was a complex one, with interwoven strands associated with rights, legality, and ownership. The debate operated on several scales. Locally, it was a conflict over how best to manage and use an area of open space in the West End of London. On a larger scale, it was part of an ongoing struggle between the authorities, local elites, reformers, radicals, and popular movements over control of space, and therefore the possibility of dissent, on a national level.

\section{The Spatialised Negotiation of Social Norms}

Tim Cresswell argues that places are used to enforce regimes of normative behaviour; people and activities are judged as 'in place' or 'out of place' according to social norms. Different places develop sets of unspoken rules that reinforce and complement official regulations about which behaviours and activities are acceptable. ${ }^{70}$ In the mid nineteenth century, these regimes were enforced within urban parks in a variety of ways. Fences and gates were used to control access, and park keepers patrolled and cooperated with local police. ${ }^{71}$ The material fabric of parks was also used to encourage normative behaviour. For example, Avenham Park in Preston, Lancashire, was designed so visitors would always be visible to other park users, encouraging good behaviour through peer pressure. ${ }^{72}$ These processes were operating in Hyde Park in the mid-nineteenth century, as they do to this day. An editorial from the Morning Post on 26 July 1866 is an excellent example of these social norms in action:

The Government ... conceive that they have the right of preventing meetings for political purposes in the royal parks, just as they have the right of prohibiting preaching, or cricketplaying, or many other things which they conceive to be out of place in the grounds intended for the amusement and recreation of the community. ${ }^{73}$

This quote is a clear illustration of how some activities were tolerated in Hyde Park, whilst others were considered inappropriate or 'out of place.' The discourse of social norms was an important element in the contestation of Hyde Park. Supporters of Mayne's ban pointed out that lots of activities were not 
tolerated in Hyde Park, and that political demonstrations were banned in public parks across the country. ${ }^{74}$ Supporters of the Reform League called attention to other large, albeit less political, events that were held in Hyde Park on a regular basis. Thinking about this mobilisation of past behaviour and regulations allows us to consider the role that social norms played in the ways in which Hyde Park was understood as a public space. Undoubtedly powerful regulators of behaviour, social norms are open to interpretation and negotiation because they can be defied. Acting 'out of place' suggests new interpretations of place, which can become established and create new social norms. ${ }^{75}$ As such, they can be employed both by those trying to regulate public space and those attempting to make new claims upon it.

In the House of Lords on 24 July, the Liberal MP Earl Granville typified the practice of highlighting other banned activities. He argued that there must be a legal justification for banning the meetings, otherwise the other rules in Hyde Park would also have no legal basis. ${ }^{76}$ Granville used all the other activities that were restricted or not permitted to argue that there must also be grounds for forbidding political demonstrations. The status quo was justified because it was the status quo.

An extension of this reliance on rules and regulations was a fear that should this one political demonstration be allowed, it would change the way people used the park permanently. For example, in the House of Commons on 24 July, William Cowper-Temple, Liberal MP for Hertford, said the following:

Such meetings had for some years been forbidden, because, if they were once permitted, the Park would become the ordinary area for the holding of such meetings, and the discussion of various subjects... There was not a temperance society that would not be wanting to expound its principles in Hyde Park, and the managers of school feasts would fix upon the Parks as appropriate spots for eating buns and drinking ginger-beer. Now this would materially interfere with the ordinary enjoyment and recreation of the public. ${ }^{77}$

Cowper-Temple was concerned that allowing political demonstrations in London's parks would fundamentally alter their character for the worse. A change in the literal rules that governed Hyde Park would result in a shift in the unspoken rules, or the social norms, which regulated behaviour in the park. In most spaces, protests and demonstrations are transgressive acts, because they defy the social and behavioural norms that typically hold sway over a space. As such, they create the possibility for change because they reveal those norms to be mutable; they are not fundamental laws which cannot be altered. Following Massey, I argue that this mutability made Hyde Park a political space. For Cowper-Temple and other members of the political elite, this mutability was something to fear. 
Opponents of the ban were not necessarily trying to redefine the social norms that governed the park, however. Some argued that the demonstration was consistent with the park's unspoken rules. They provided examples of when Hyde Park had been used for other events involving large numbers of people, including reviews of volunteer soldiers, parades by Foot Guards, and even the Great Exhibition in $1850 .{ }^{78}$ Yet none of these examples were overtly political events, which was what set them apart from the Reform League's demonstration in the eyes of the Government and the Metropolitan Police. Rather than presenting the demonstration as an attempt to change the rules and social norms that governed Hyde Park, those who opposed Mayne's ban tried to show that the demonstration was in keeping with the status quo.

This use of precedents and social norms to support conflicting viewpoints demonstrates how subjective understandings of public space can be. Whilst social and behavioural norms can be powerful controls over what kinds of behaviour are performed in different spaces, they are mutable, and open to constant (re)negotiation and alteration. Their unspoken nature contributes to their mutability, and their lack of fixed definition leaves them open to interpretation. As such, they can be utilised differently by different people and for different purposes, as in the case of the Hyde Park Railings Affair.

"Invaded by a miscellaneous assortment of radicals from Holborn and Clerkenwell": The Intersections of Class, Power, and Geography ${ }^{79}$

London's geography is shot through with relations of power, class, and inequality, and has been since long before $1866 .^{80}$ Londoners of different socio-economic groups had separate locales for work, accommodation, and recreation. As today, there were significant cultural, social, and economic gaps between the city's rich and poor. ${ }^{81}$ London's parks, portrayed by social and political elites as spaces where different social classes could mingle and interact, reproduced those divisions. ${ }^{82}$ These partitions, and their geographical manifestations, are clearly visible within the debate surrounding the Hyde Park Railings Affair.

For many of those who supported the Reform League's right to meet in Hyde Park, the issue was not just about having a location in which to meet, but also being able to meet in a place which would render them visible to those in power. Few working-class men, and no women, were able to vote in the 1860 s, so attending a public meeting was one of the limited options available for making one's voice heard. Radical groups believed that the closer this meeting was to the Government's seat of 
power in Westminster, and the wealthy people who lived in the West End around Hyde Park, the harder it would be for elites to ignore their concerns. The Birmingham Daily Post published an account of a meeting of the Birmingham Working Men which took place two days after the protest on 25 July, where they discussed the events in Hyde Park. ${ }^{83}$ In the months before the Hyde Park Railings Affair, the political elite had asserted that the working class did not want the vote, challenging groups like the Reform League to prove otherwise. This was part of the rationale behind the planned demonstration, as Arthur O'Neill, who chaired the meeting of Birmingham Working Men, asserted: "Hyde Park was surrounded by those classes that had been insulting the people for the last several months; and therefore, it was necessary that they should take their views and themselves, quietly and calmly, to look the gentry in the face-[cheers] - and show them that the multitude of the working classes were for reform." ${ }^{84}$ The Caledonian Mercury recognised that "Hyde Park, with its surrounding city of palaces, appeals from its very position to class feeling." ${ }^{85}$ For Reformers such as O'Neill, Hyde Park's location close to the physical and metaphorical seat of power in Britain, not just London, was a factor in what made the park such a desirable location for political demonstrations.

This symbolic nature of Hyde Park's location likely also contributed to the Government's decision to ban the demonstration. In the House of Commons on 24 July Henry Jervis, a Conservative MP, argued that the purpose of holding a public meeting in Hyde Park was to intimidate MPs, and therefore unfairly influence Parliament:

the working men ... wished to assemble in Hyde Park in order to let the people of the West End of the town know what they thought on the subject of Reform. Why, what was the meaning of this? Simply to endeavour to intimidate the Members of this House, most of whom lived at the West End. But hon. Members were sent to the House of Commons to act on behalf of the people of England as a whole, and therefore he must protest against meetings being held for the purpose of intimidating country Members, and forcing them to act against their better judgement." ${ }^{\prime 86}$

Jervis' concerns were an acknowledgement that Hyde Park's symbolic significance depended on its proximity to both London's wealthiest residents, and Britain's political centre in Westminster.

The geographical distributions of power and inequality in London also played out through arguments about which groups of people were tolerated in Hyde Park, and who had influence over how the Park was managed. In the House of Commons on 24 July, Acton Smee Ayrton, Liberal MP for Tower Hamlets and staunch reformer, made a speech in favour of the people's right to hold demonstrations in Hyde Park. ${ }^{87}$ Ayrton argued that wealthy elites had appropriated certain sections of the royal parks for their 
own convenience and recreation, including activities that were not accessible to the majority of Londoners, such as riding in a carriage. ${ }^{88}$

Ayrton was not the only one that thought that the upper classes had more power over how Hyde Park was managed and used than everyone else. The Freeman's Journal and Daily Commercial Advertiser, published in Dublin, describes a satirical poster that appeared on London's streets after the Hyde Park Railings Affair: “with the catching headline 'Wanted!' [it] was a call for '10,000 costermongers, mounted on their donkeys, to parade Rotten-row,' for the purpose of testing 'the question whether this portion of Hyde Park belongs to a class or to the entire people." ${ }^{\prime 9}$ Rotten Row was originally built to connect St. James's Palace and Kensington Palace for the Royal family, and was a popular place for London's rich and famous to ride by the mid eighteenth century. ${ }^{90}$ As such, it was probably one of the areas of the park most strongly associated with the upper classes in 1866, so would have been an appropriate place to challenge perceived class-based exclusionary practices in the Park. Examples such as these demonstrate that the ability to access and influence Hyde Park as a public space was perceived as being differentiated by class. A wide range of socio-economic factors, including gender, ethnicity, age, and income can affect whether or not an individual feels comfortable entering a particular public space, or indeed whether they are welcomed by other users of that space. ${ }^{91}$ As Anthony Taylor argues, parks "reinforced existing social divisions in London. The landscape of the parks was a controlled environment of winding paths and close-cropped flower borders that fulfilled bourgeois fantasies of a tamed natural landscape;" they did not cater to the recreational tastes of the working classes. ${ }^{92}$ London's working classes may well have felt excluded from Hyde Park because it was not designed for them. The debate surrounding the Hyde Park Railings Affair was an opportunity for these grievances to be aired.

This class-based exclusion also had a geographical dimension. Whether or not one had the right to access Hyde Park was not simply based on socio-economic status, but also which part of London one came from, as reflected in this editorial in the right-wing Times on 24 July:

Parliament has endowed London with a number of these pleasure-grounds; there is Hydepark for the West-end, St. James's Park for Westminster, Victoria and Greenwich Parks from the east and south-east of the metropolis, Regent's Park for the north, and Battersea for the south. If political agitators really did wish to harangue in Parks, one would think they might be content to use those which are nearest to them. But here we have the extremest regions of London placarded with invitations to the lowest class of their inhabitants to occupy a Park which is the ordinary place of recreation for the people living 
in the west of London. It is against all reason and justice that motley crowds from all parts of the metropolis should take possession of Hyde Park, and interfere with the enjoyment of those to whom the park more particularly belongs. ${ }^{93}$

The author is stating in no uncertain terms that the "lowest class" of Londoners from other parts of the city are not welcome in a park that "particularly belongs" to the people who live in West London. As has already been noted, the areas surrounding Hyde Park were home to some of the city's wealthiest and most powerful residents. London's class divisions were manifest in the city's geography, and this in turn influenced understandings of who was welcome in Hyde Park, and who it 'belonged' to. This illustrates how access to public space can be differentiated geographically; where a person comes from can impact their right to enter a particular public space.

\section{Conclusions}

Creating a space that is truly public is not just about the ability to access said space, but also about being able to influence which practices and behaviours are considered acceptable within it. As the example of the Hyde Park Railings Affair demonstrates, obtaining the right to access and control public space is a complicated process influenced by multiple factors including power, class, geography, and social norms. Public spaces and the social norms which dictate how they are used are malleable, open to interpretation, negotiation, and contestation. This means that public space is not only a location for protest and acts of dissent, it can also be the motivation for resistance. Protest is shaped by public space because of the rules and conditions that govern it; the Hyde Park Railings Affair escalated into a riot because the Government declared that mass meetings in the park were against the rules and tried to enforce that ruling. However, public space is in turn shaped by protest; debates around the Hyde Park Railings Affair were part of a longer conversation that eventually led to the foundation of Speaker's Corner, a designated area for free and political speeches that was created by the 1872 Parks Regulation Act.

The debate about the Hyde Park Railings Affair also illustrates how people justify their claim over public space. A wide range of arguments were utilised, including: Hyde Park's suitability as a location for mass meetings, ownership of the park, financial contributions to the upkeep of the park through taxes, adherence to the pre-existing rules, social norms governing the park, and even proximity of one's home to the park. This is significant because it contributes to our understandings of why people feel they have a right to access and influence public space, and can provide insight into contemporary conflicts over increasingly privatised and regulated public spaces. The debates that played out in Parliament and the British media in 1866 also highlight how conflicting understandings of the purpose 
of public space can fuel debate; questions about whether public space is for protest and debate or leisure and recreation resonate to this day. In this way, this article furthers our understanding of the geographies of public space and protest, both past and present.

The Hyde Park Railings Affair took place at a time when radical movements had to fight the authorities for spaces in which to meet, discuss, and organise. With the increasing restrictions on public space and the rise of right-wing authoritarian governments around the world, modern activists are facing a similar struggle. The right to access and influence public space is an important one, and it is by no means guaranteed. By understanding how this right was both defended and contested in the past, we can contribute to the defence of that right in the present.

\section{Acknowledgments}

The research for this article was undertaken during my PhD at Royal Holloway, University of London, which was funded by the ESRC. I would like to thank my PhD supervisors, Innes Keighren and David Gilbert, for their support. Thanks are also due to Briony McDonagh, Ruth Slatter, and the two anonymous referees for their constructive comments on earlier drafts.

\footnotetext{
${ }^{1}$ Antonia Layard, "Property Paradigms and Place-making: A Right to the City," Journal of Human Rights and the Environment 3, no. 2 (2012): 254-272; Antonia Layard, "Public Space: Property, Lines, Interruptions," Journal of Law, Property and Society 2, no. 1 (2016): 1-47; Setha M. Low, On the Plaza: The Politics of Public Space (Austin: University of Texas Press, 2000); Setha Low and Neil Smith (eds) The Politics of Public Space (London: Routledge, 2006); Don Mitchell, The Right to the City: Social Justice and the Fight for Public Space (New York: The Guildford Press, 2003).

${ }^{2}$ Hazel Conway, People's Parks: The Design and Development of Victorian Parks in Britain (Cambridge: Cambridge University Press, 1991); The Royal Parks, "About Us: Who We Are." No date, accessed July 12, 2019, https://www.royalparks.org.uk/about-us/who-we-are.

3 Anthony Taylor, “'Commons-Stealers,' 'Land-Grabbers' and 'Jerry-Builders': Space, Popular Radicalism and the Politics of Public Access in London, 1848-1880," International Review of Social History 40 (1995): 383-407.

${ }^{4}$ Paul Rabbitts, Hyde Park: The People's Park (Stroud, Gloucestershire: Amberley, 2015).

${ }^{5}$ Conway, People's Parks; Angela Loxham, "The Uses and Abuses of Public Space: Urban Governance, Social Ordering and Resistance, Avenham Park, Preston, c.1850-1901," Journal of Historical Sociology 26, no. 4 (2013): 552-575.
} 
${ }^{6}$ Conway, People's Parks; Paul Elliot, Stephen Daniels, and Charles Watkins, "The Nottingham Arboretum (1852): Natural History, Leisure, and Public Culture in a Victorian Regional Centre," Urban History 35, no. 1 (2008): 48-71; Hilary A. Taylor, "Urban Public Parks, 1840-1900: Design and Meaning," Garden History 23, no. 2 (1995): 201-221.

${ }^{7}$ David Killingray, "Rights, 'Riot' and Ritual: The Knole Park access Dispute, Sevenoaks, Kent, 1883-5," Rural History 5, no. 1 (1994): 63-79.

${ }^{8}$ Neil MacMaster, “The Battle for Mousehold Heath 1857-1884: 'Popular Politics' and the Victorian Public Park," Past and Present, 127 (1990): 117-154; Ben Cowell, "The Commons Preservation Society and the Campaign for Berkhamsted Common, 1866-70," Rural History 13, no. 2 (2002): 145-161; Robert Allen, "The Battle for the Common: Politics and Populism in mid-Victorian Kentish London," Social History 22, no. 1 (1997): 61-77; David Killingray, "Rights, 'Riot' and Ritual."

${ }^{9}$ Anthony Taylor, "'Commons-Stealers,' 'Land-Grabbers' and 'Jerry-Builders'."

${ }^{10} J o h n$ Michael Roberts, "The Enigma of Free Speech: Speakers' Corner, the Geography of Governance and a Crisis of Rationality," Social and Legal Studies 9, no. 2 (2000): 271-92.

${ }^{11}$ Roberts, "The Enigma of Free Speech," 283. See also Davina Cooper, "'Sometimes a Community and Sometimes a Battlefield': From the Comedic Public Sphere to the Commons of Speakers Corner," Environment and Planning D 24, no. 5 (2006): 753-75.

12 Stephen Vella, "Newspapers," in Miriam Dobson and Benjamin Ziemann (eds) Reading Primary Sources: The Interpretation of Texts from Nineteenth and Twentieth Century History (Abingdon: Routledge, 2009): 191-208, 193.

${ }^{13}$ Vella, "Newspapers."

${ }^{14}$ Thomas McFarlane and lain Hay, "The Battle for Seattle: Protest and Popular Geopolitics in The Australian Newspaper," Political Geography 22, no. 2 (2003): 211-32, 212.

${ }^{15}$ George Rudé, The Crowd in History (London: Serif, 2005 [1964]).

${ }^{16}$ Carl J. Griffin, "'Cut Down by Cowardly Miscreants': Plant Maiming, or the Malicious Act of Cutting Flora, as an Act of Protest in Eighteenth- and Nineteenth-Century Rural England," Rural History 19, no. 1 (2008): 29-54.

${ }^{17}$ See, for example, John R. Parkinson, Democracy and Public Space: The Physical Sites of Democratic Performance (Oxford: Oxford University Press, 2012); Richard Sennett, The Fall of Public Man (Cambridge: Cambridge University Press, 1977).

${ }^{18}$ Nick Blomley, "Public Space," in Derek Gregory et al. (eds) The Dictionary of Human Geography, 5th edition (Chichester: Wiley-Blackwell, 2009): 602.

${ }^{19}$ Antonia Layard, "Public Space."

${ }^{20}$ Setha M. Low, On the Plaza. 
${ }^{21}$ See, for example, Mitchell, The Right to the City.

22 Don Mitchell, "The End of Public Space? People's Park, Definitions of the Public, and Democracy," Annals of the Association of American Geographers 85, no. 1 (1995): 108-33; Don Mitchell, "People's Park Again: On the End and Ends of Public Space," Environmental and Planning A 49, no. 3 (2017): 503-518.

${ }^{23}$ Don Mitchell, "The Liberalization of Free Speech: Or How Protest in a Public Space is Silenced," in Walter Nicholls, Byron Miller and Justin Beaumont (eds) Spaces of Contention: Spatialities and Social Movements (Farnham, Surrey: Ashgate, 2013): 47-67.

${ }^{24}$ Katrina Navickas. Protest and the Politics of Space and Place, 1789-1848 (Manchester: Manchester University Press, 2016).

${ }^{25}$ Anthony Taylor, "'Commons-Stealers,' 'Land-Grabbers' and 'Jerry-Builders'."

${ }^{26}$ Lisa Keller, Triumph of Order: Democracy and Public Space in New York and London (New York: Columbia University Press, 2009).

${ }^{27}$ Notable recent contributions to the historical geography of protest include: Carl Griffin, The Rural War: Captain Swing and the Politics of Protest (Manchester: Manchester University Press, 2012); Carl Griffin, Protest, Politics and Work in Rural England (Basingstoke: Palgrave, 2014); Carl J. Griffin and Briony McDonagh (eds.) Remembering Protest since 1500: Memory, Materiality and the Landscape (Cham, Switzerland: Palgrave Macmillan, 2018); Paul Griffin, "Labour Struggles and the Formation of Demands: The Spatial Politics of Red Clydeside," Geoforum 62 (2015): 121-130; Diarmaid Kelliher, "Constructing a Culture of Solidarity: London and the British Coalfields in the Long 1970s," Antipode 49, no. 1 (2017): 106-124; Briony A. K. McDonagh, "Subverting the Ground: Private Property and Public Protest in the Sixteenth-Century Yorkshire Wolds," The Agricultural History Review 57, no. 2 (2009): 191-206; Briony McDonagh, "Making and Breaking Property: Negotiating Enclosure and Common Rights in Sixteenth-Century England," History Workshop Journal 76, no. 1 (2013): 32-56; lain J. M. Robertson Landscapes of Protest in the Scottish Highlands after 1914: The Later Highland Land Wars (London: Routledge, 2013).

${ }^{28}$ Doreen Massey, For Space (London: SAGE, 2005), 11.

${ }^{29}$ David Featherstone and Paul Griffin, "Spatial Relations, Histories from Below and the Makings and Agency: Reflections on The Making of the English Working Class at 50," Progress in Human Geography 40, no. 3 (2016): 375-393.

${ }^{30}$ Christina Parolin, Radical Spaces: Venues of Popular Politics in London, 1790-c.1845 (Canberra: The Australian National University E Press, 2010).

${ }^{31}$ Paul Routledge, Space Invaders: Radical Geographies of Protest (London: Pluto, 2017). 
32 See, for example, Deborah Martin and Byron Miller, "Space and Contentious Politics," Mobilization 8, no. 2 (2003): 143-156; Steve Pile and Michael Keith (eds) Geographies of Resistance (London: Routledge, 1997); William Sewell, "Space in Contentious Politics," in Ronald R. Aminzade et al (eds) Silence and Voice in the Study of Contentious Politics (Cambridge: Cambridge University Press, 2001): $51-88$.

${ }^{33}$ Sam Halvorsen, "Encountering Occupy London: Boundary Making and the Territoriality of Urban Activism," Environment and Planning D 33, no. 2 (2015): 314-330; Sam Halvorsen, "Spatial Dialectics and the Geography of Social Movements: The Case of Occupy London," Transactions of the Institute of British Geographers 42, no. 3 (2017): 445-457.

34 Mattias Wahlström, "Producing Spaces for Representation: Racist Marches, Counterdemonstrations, and Public-order Policing," Environment and Planning D 28, no. 5 (2010): 811-827.

35 Paul Foot, The Vote: How it was Won and How it was Undermined (London: Bookmarks, 2012 [2005]).

${ }^{36}$ Dorothy Thompson, The Chartists: Popular Politics in the Industrial Revolution (Aldershot: Wildwood House, 1986).

${ }^{37}$ Aldon D. Bell, "Administration and Finance of the Reform League, 1865-1867," International Review of Social History 10, no. 3 (1965): 385-409.

${ }^{38}$ Foot, The Vote.

${ }^{39}$ The ban was published in several newspapers, but for an example see Richard Mayne, "NoticeMeeting in Hyde Park," Pall Mall Gazette (London) July 19, 1866, accessed April 11, 2014, $19^{\text {th }}$ Century British Library Newspapers Online Archive.

${ }^{40}$ Anon., "Summary of this Morning's News," Pall Mall Gazette (London) July 10, 1866, accessed March 29, 2014, 19th Century British Library Newspapers Online Archive.

${ }^{41}$ British Library, [hereafter BL], 8138bbb45 Anon. The Government and the People! The Great Reform League Demonstration in Hyde Park. London: F. Farrah, 1866.

${ }^{42} \mathrm{BL}, 8138 \mathrm{bbb} 45$.

${ }^{43} \mathrm{BL}, 8138 \mathrm{bbb} 45$.

${ }^{44}$ Senate House Library [hereafter SHL], [G.L.] 1866 Anon. A Full and Interesting Account of the Meetings held in Hyde Park in Favour of Parliamentary Reform... London: Butland and Co., 1866.

${ }^{45} \mathrm{BL}, 8138 \mathrm{bbb} 45$.

${ }^{46}$ BL, 8138bbb45; BL, MFR1187 John Bedford Reno. The Aftermath: With Autobiography of the Author. London: Reeves and Turner, 1892.

${ }^{47}$ BL, MFR1187; BL, 8138bbb45. 
${ }^{48} \mathrm{BL}, 8138 \mathrm{bbb} 45$.

${ }^{49}$ House of Commons Debate, 19 July 1866, vol. 184, cc1073-5.

${ }^{50}$ House of Commons Debate, 19 July 1866, vol. 184, cc1073-5.

${ }^{51}$ House of Commons Debate, 19 July 1866, vol. 184, cc1073-5.

52 House of Commons Debate, 19 July 1866, vol. 184, cc1073-5.

${ }^{53}$ Don Mitchell, "The Liberalization of Free Speech," 47.

${ }^{54}$ Anon., "The Hyde Park Riots," Liverpool Mercury etc. (Liverpool) July 26, 1866, accessed April 11, 2014, 19th Century British Newspapers Online Archive.

${ }^{55}$ Don Mitchell, "The End of Public Space?"

${ }^{56}$ Anon., "London, Saturday, July 21, 1866," The Morning Post (London) July 21, 1866, accessed March 31, 2014, 19th Century British Newspapers Online Archive.

${ }^{57}$ Anon., "London, Tuesday, July 24," Daily News (London) July 24, 1866, accessed March 31, 2014, 19th Century British Newspapers Online Archive.

${ }^{58}$ Anon., "The Hyde Park disturbance is a circumstance...," The Leeds Mercury (Leeds) July 25, 1866, accessed March 31, 2014, 19th Century British Newspapers Online Archive.

${ }^{59}$ Routledge, Space Invaders.

${ }^{60}$ Sam Halvorsen, "Encountering Occupy London."

${ }^{61}$ Anon., "If one could believe that the abstract right to hold public meetings in London were in any danger...," The Caledonian Mercury (Edinburgh) July 25, 1866, accessed March 31, 2014, 19th Century British Newspapers Online Archive.

62 Anon., "The Proposed Meeting in Hyde Park," Birmingham Daily Post (Birmingham) July 24, 1866, accessed March 31, 2014, 19th Century British Newspapers Online Archive. These letters were also published in other newspapers.

63 Katrina Navickas, Protest and the Politics of Space and Place, 1789-1848; Anthony Taylor, “'Commons-Stealers,' 'Land-Grabbers' and 'Jerry-Builders'."

${ }^{64}$ Christina Parolin, Radical Spaces: Venues of Popular Politics in London, 1790-c.1845; Anthony Taylor,

“'Commons-Stealers,' 'Land-Grabbers' and 'Jerry-Builders'."

${ }^{65}$ Antonia Layard, "Property Paradigms and Place-making"; Antonia Layard, "Public Space."

${ }^{66}$ House of Commons Debate, 24 July 1866, vol. 184, cc1385-416.

${ }^{67}$ This right is asserted numerous times in texts analysed here. See, for example, Anon., "News of the Day," Birmingham Daily Post (Birmingham) July 23, 1866, accessed March 31, 2014, 19th Century British Newspapers Online Archive; Anon., "The Proposed Meeting in Hyde-park," Daily News (London) July 21, 1866, accessed March 29, 2014, 19th Century British Newspapers Online Archive; Anon. "The Hyde-park Reform Meeting," Freeman's Journal and Daily Commercial Advertiser (Dublin) 
July 25, 1866, accessed March 31, 1866, 19th Century British Newspapers Online Archive; Anon., "The Hyde Park Disturbances," The Caledonian Mercury (Edinburgh) July 26, 1886, accessed April 11, 2014, 19th Century British Newspapers Online.

${ }^{68}$ Anon., "The Hyde Park Reform Meeting. Meeting of Birmingham Working Men," Birmingham Daily Post (Birmingham) July 26, 1866, accessed April 11, 2014, 19th Century British Newspapers Online; Anon., "The Proposed Meeting in Hyde Park," Birmingham Daily Post (Birmingham) July 24, 1866, accessed March 31, 2014, 19th Century British Newspapers Online; Anon., "The Hyde Park Demonstration," Birmingham Daily Post (Birmingham) July 25, 1866, accessed March 31, 2015, 19th Century British Newspapers Online; Anon., "News of the Day," Birmingham Daily Post (Birmingham) July 25, 1866, accessed March 31, 2014, 19th Century British Newspapers Online; Anon., "The Hyde Park Demonstration," Daily News (London) July 24, 1866, accessed March 31, 2014, 19th Century British Newspapers Online; Anon., "Police Prohibition of the Public Meeting," Reynold's Newspaper (London) July 22, 1866, accessed March 31, 2014, 19th Century British Newspapers Online.

69 "Police Prohibition of the Public Meeting," Reynold's Newspaper (London) July 22, 1866, accessed March 31, 2014, 19th Century British Newspapers Online.

${ }^{70}$ Tim Cresswell, In Place/Out of Place (Minneapolis: University of Minnesota Press, 1996).

${ }^{71}$ Anthony Taylor, "'Commons-Stealers,' 'Land-Grabbers' and 'Jerry-Builders'."

${ }^{72}$ Angela Loxham, "The Uses and Abuses of Public Space"; Hilary A. Taylor, "Urban Public Parks: 18401900."

${ }^{73}$ Anon., "A placard having been extensively circulated on..." The Morning Post (London) July 26, 1866, accessed April 11, 2014, 19 ${ }^{\text {th }}$ Century British Newspaper Online, italics by author.

${ }^{74}$ House of Commons Debate, 24 July 1866, vol. 184, cc1385-416; C.B. Adderley, "The Hyde Park Riots," The Times (London) July 26, 1866, accessed April 1, 2014, The Times Online Archive 1785-2013. 75 Tim Cresswell, "Putting Women in their Place: The Carnival at Greenham Common." Antipode 26, no. 1 (1994): 35-58.

${ }^{76}$ House of Lords Debate, 24 July 1866, vol. 184, cc1370-5.

${ }^{77}$ A.F Pollard, revised by H.C.G Matthew, "Temple, William Francis Cowper-, Baron Mount-Temple," Oxford Dictionary of National Biography. Last modified September 23, 2004, accessed January 23, 2019, https://doi.org/10.1093/ref:odnb/6515; House of Commons Debate, 24 July 1866, vol. 184, cc1385-416.

${ }^{78}$ Anon., "The Hyde Park Reform Meeting. Meeting of Birmingham Working Men," Birmingham Daily Post (Birmingham) July 26, 1866, accessed April 11, 2014, 19th Century British Newspapers Online; Anon., "The Hyde Park Meeting," Freeman's Journal and Daily Commercial Advertiser (Dublin) July 24, 1866, accessed March 31, 2014, 19th Century British Newspapers Online; Anon., "The Proposed Great 
Reform Meeting in Hyde Park," Reynold's Newspaper (London) July 8, 1866, accessed March 28, 2014, 19th Century British Newspapers Online; Anon., "Police Prohibition of the Right of Public Meeting," Reynold's Newspaper (London) July 22, 1866, accessed March 31, 2014, 19th Century British Newspapers Online.

79 Anon., "The organisers of the "demonstration" to be attempted this evening..." The Standard (London) July 23, 1866, accessed March 31, 2014, 19th Century British Newspapers Online.

${ }^{80} \mathrm{C}$ Hamnett and D Cross, "Social Polarisation and Inequality in London: The Earnings Evidence, 197997," Environment and Planning C 16, no. 6 (1998): 659-680.

81 Jerry White, London in the $19^{\text {th }}$ Century (London: Vintage, 2008).

82 House of Commons Debate, 24 July 1866, vol. 184, cc1385-416; Conway, People's Parks.

${ }^{83}$ Anon., "The Hyde Park Reform Meeting. Meeting of Birmingham Working Men," Birmingham Daily Post (Birmingham) July 26, 1866, accessed April 11, 2014, 19th Century British Newspapers Online;

${ }^{84}$ Anon., "The Hyde Park Reform Meeting. Meeting of Birmingham Working Men," Birmingham Daily Post (Birmingham) July 26, 1866, accessed April 11, 2014, 19th Century British Newspapers Online; Anon., "Police Prohibition of the Right of Public Meeting," Reynold's Newspaper (London) July 22, 1866, accessed March 31, 2014, 19th Century British Newspapers Online.

${ }^{85}$ Anon. "If one could believe that the abstract right to..." Caledonian Mercury (Edinburgh) July 25, 1866, accessed March 31, 2014, 19th Century British Newspapers Online.

${ }^{86}$ House of Commons Debate, 24 July 1866, vol. 184, cc1385-416.

87 W.P Courtney, revised by H.C.G. Matthew. "Ayrton, Acton Smee," Oxford Dictionary of National Biography. Last modified September 23, 2004, accessed January 23, 2019, https://doi.org/10.1093/ref:odnb/947

${ }^{88}$ House of Commons Debate, 24 July 1866, vol. 184, cc1385-416.

${ }^{89}$ Anon., "The Hyde-park Demonstration. Full Particulars," Freeman's Journal and Daily Commercial Advertiser (Dublin) July 25, 1866, accessed March 31, 2014, 19th Century British Newspapers Online. ${ }^{90}$ Rabbitts, Hyde Park.

${ }^{91}$ See, for example Rachel H. Pain, "Social Geographies of Women's Fear of Crime," Transactions of the Institute of British Geographers 22, no. 2 (1997); 231-244.

${ }^{92}$ Anthony Taylor, "“Commons-Stealers", "Land-Grabbers" and "Jerry-Builders"."

${ }^{93}$ Anon., "We trust that Mr. BEALES and his friends are satisfied..." The Times (London) July 24, 1886, accessed April 1, 2014, The Times Digital Archive 1785-2013. 